\title{
RESPONS PELAJAR INSTITUT PENGAJIAN TINGGI AWAM TERHADAP PLURALITI AGAMA DI MALAYSIA
}

RESPONSE AMONG THE STUDENTS OF THE PUBLIC HIGHER LEARNING INSTITUTION TOWARDS RELIGIOUS PLURALITY IN MALAYSIA

\section{Mohd Farid Mohd Sharif", Khadijah Mohd Khambali @ Hambali* $^{* *}$}

*Islamic Studies Section. School of Humanities. Universiti Sains Malaysia. 11800 Pulau Pinang. Malaysia.

** Department of Aqidah \& Islamic Thought. Academy of Islamic Studies. University of Malaya. 50603. Kuala Lumpur. Malaysia.

Emel: *faridusm@usm.my

\begin{abstract}
Khulasah
Kajian ini bertujuan untuk menganalisis respons dalam kalangan pelajar Institut Pengajian Tinggi Awam terhadap pluraliti agama dalam konteks masyarakat plural di Malaysia. Kajian ini melibatkan seramai 800 responden yang dipilih dari empat buah IPTA. Data kajian diperolehi melalui soal selidik yang dianalisis menggunakan program SPSS. Statistik deskriptif melalui frekuensi, peratusan, min, statistik jadual silang dan correlation coefficient digunakan dalam kajian bagi menerangkan latar belakang responden dan respons pelajar terhadap pluraliti agama. Hasil kajian menunjukkan penerimaan pelajar terhadap pluraliti agama tidak begitu baik seperti setiap agama adalah benar, setiap individu mesti mengetahui prinsip asasi agama lain sebagai pra syarat dalam masyarakat plural, kebebasan beragama ialah hak setiap individu. Dapatan kajian juga menunjukkan faktor agama dan jenis pendidikan sekolah rendah dan menengah mempunyai pengaruh yang besar ke atas respons pelajar terhadap pluraliti agama.
\end{abstract}


Kata kunci: Pluraliti; IPTA; respons; plural; agama.

\begin{abstract}
This study was aimed to analyse the response among the students of the Public Higher Learning Institution (IPTA) towards religious plurality in the context of pluralist society in Malaysia. The study involved 800 respondents selected from four IPTAs. The data of the study collected through questionnaire and analysed by SPSS programme. Descriptive statistic through frequency, percentage, min, crosstabulation and correlation coefficient were applied in this study to explain the respondent's background and the student's response towards religious plurality. The findings showed that the reception of the students towards religious plurality were reasonably bad, i.e., every religion is true, every individual must know other religion principles as precondition for making pluralist society, religious freedom is a right for everyone. The findings also indicated that the religion factor and the types of education of primary and secondary school were enormously influential over the student's response towards religious plurality.
\end{abstract}

Keywords: Plurality; IPTA; response; plural; religious.

\title{
Pendahuluan
}

Al-Quran memberi kelonggaran ruang dan peluang kepada orang Islam untuk menjalinkan hubungan dan interaksi dengan orang bukan Islam selagi mereka tidak memusuhi Islam dan tidak memusuhi orang Islam. Hal ini dijelaskan dalam al-Quran seperti berikut:

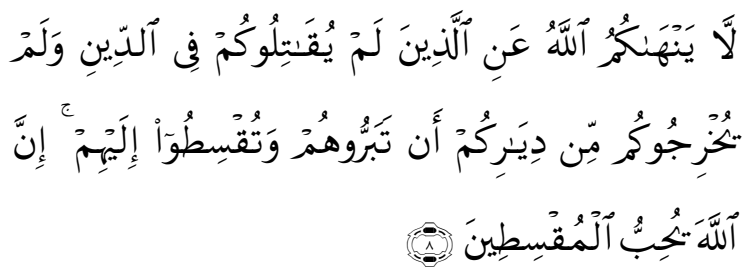


Terjemahan: Allah tidak melarang kamu terhadap orang-orang yang tidak memerangi kamu kerana agama, dan tidak mengeluarkan kamu dari kampung halaman untuk berbuat baik dan berlaku adil kepada mereka; sesungguhnya Allah mengasihi orang-orang yang berlaku adil

\section{Al-Mumtahanah 60:8}

Selain itu, terdapat satu contoh bagaimana Nabi Muhammad SAW bersikap adil kepada komuniti Yahudi di Khaybar dalam satu kes homisid. Dalam kes itu, menurut riwayat Sa'd bin Abī Hathamah, seorang lelaki dari kaum Ansar bernama 'Abd Allāh bin Sahl telah didapati terbunuh. Pembunuhan ini kebetulan berlaku dalam kawasan kejiranan komuniti Yahudi lantas menimbulkan syak bahawa pembunuhnya ialah orang Yahudi. Namun disebabkan tidak ada satu pun bukti yang boleh digunakan untuk menyokong tuduhan itu, maka Nabi Muhammad SAW tidak menjatuhkan hukuman kepada mana-mana orang Yahudi di Khaybar. Sebaliknya hanya meminta mereka supaya bersumpah bahawa mereka tidak pernah melakukan pembunuhan tersebut. Walaupun terdapat sedikit tentangan daripada waris si mangsa, iaitu mereka tidak mahu menerima sumpah orang-orang Yahudi, hanya kerana mereka itu Yahudi.

Sikap sebegini jika tidak dikawal boleh menimbulkan perselisihan faham antara orang Islam dengan Yahudi. Oleh itu, Nabi Muhammad SAW tetap bertegas dengan keputusannya untuk tidak menghukum orang-orang Yahudi. Malah untuk bersikap adil kepada kaum Ansar dan sebagai satu usaha untuk memulihkan hubungan baik antara mereka, Nabi Muhammad SAW membayar 
pampasan sebanyak seratus ekor unta kepada keluarga si mangsa. ${ }^{1}$

Al-Quran juga memberikan penjelasan kepada konsep kebebasan beragama dan pada masa yang sama alQuran memberi peringatan kepada manusia bahawa agama yang hanya diterima pada sisi Allah S.W.T ialah Islam. Hal ini menjelaskan bahawa Islam tidak pernah memaksa penganut agama lain ataupun penganut bukan mana-mana agama menganut agama Islam seperti dinyatakan dalam al-Quran seperti berikut:

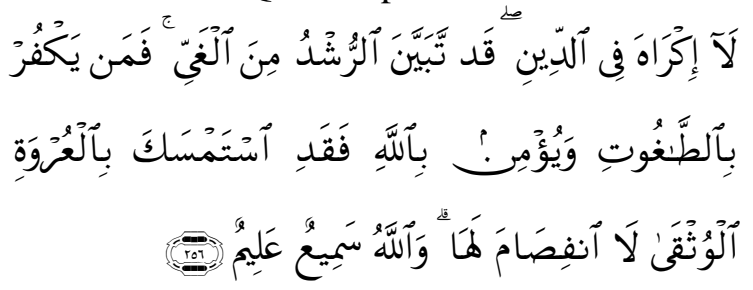

Terjemahan: Tidak ada paksaan dalam agama, kerana sesungguhnya telah nyata kebenaran dari kesesatan. Oleh itu, sesiapa yang tidak percayakan taghut, dan ia pula beriman kepada Allah, maka sesungguhnya ia telah berpegang kepada simpulan yang teguh, yang tidak akan putus. Dan Allah Maha Mendengar, lagi Maha Mengetahui.

\section{Al-Baqarah 2:256}

Selain itu, Islam menganjurkan agar manusia sentiasa menghormati peribadi manusia lain dengan tidak menghina, mencemuh, mengeji atau memanggil dengan gelaran yang tidak disukai. ${ }^{2}$ Oleh itu, setiap manusia pada

${ }^{1}$ Șaḥịh al-Bukhārī, kitāb al-Diyāt, bāb al-Qasāmah, no. 6502; Șaḥịh Muslim, kitāb al-Qasāmah wa al-muḥaribīn wa al-qasas wa al-diyāt, bāb al-Qasāmah, no. 1669.

2 Lihat Abul A'la Mawdudi, Towards Understanding Islam (Markfield: The Islamic Foundation, 2000), 107; Noor Shakirah Mat Akhir, AlGhazali and His Theory of the Soul: A Comparative Study (Pulau Pinang: Penerbit Universiti Sains Malaysia, 2008), 275; Mohd Farid 
asasnya perlu menghormati peribadi semua anggota masyarakat tanpa mengira apa jenis agama anutan mereka. Hal ini dijelaskan dalam al-Quran seperti berikut:

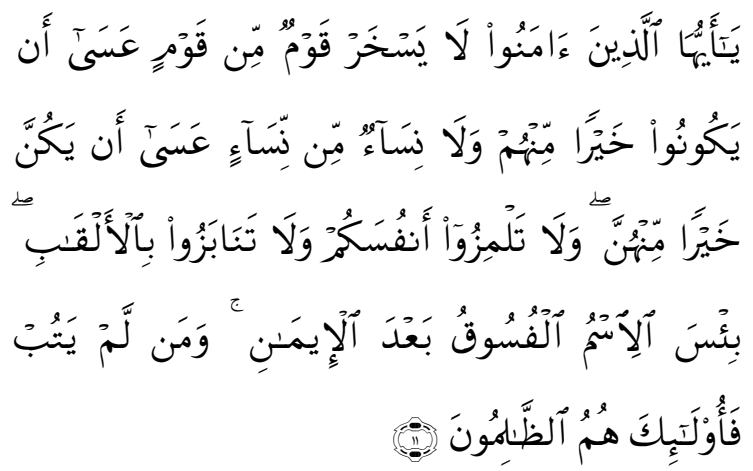

Terjemahan: Wahai orang-orang yang beriman! Janganlah sesuatu puak lelaki mencemuh dan merendah-rendahkan puak lelaki yang lain, boleh jadi puak yang dicemuhkan itu lebih baik daripada mereka; dan janganlah pula sesuatu puak perempuan mencemuh dan merendah-rendahkan puak perempuan yang lain, boleh jadi puak yang dicemuhkan itu lebih baik daripada mereka; dan janganlah setengah kamu menyatakan keaiban setengahnya yang lain; dan janganlah pula kamu memanggil antara satu sama lain dengan gelaran yang buruk. Amatlah buruk sebutan nama fasik sesudah ia beriman. Dan sesiapa yang tidak bertaubat maka merekalah orang-orang yang zalim.

Al-Hujurat 49:11

Berdasarkan kepada beberapa ayat al-Quran di atas, hal yang telah dijelaskan ialah Islam mengemukakan satu

Mohd Sharif, "Commanding and Forbidding the Imām: A Study of the Concept of al-Amr bi al-Ma'rüf and Nahy 'an al-Munkar in Islamic Imamship,” Jurnal Syariah 16(1) (2008): 14. 
formula iaitu kejadian manusia dalam bentuk pelbagai kaum dan agama merupakan satu fitrah dalam kehidupan manusia di dunia. Fitrah ini perlu diterima oleh setiap manusia. Malah kepelbagaian kaum dan agama itu secara semulajadinya mendorong pula kepada wujudnya kepelbagaian gaya hidup, corak pemikiran serta kepercayaan dan menjadikan kehidupan di dunia ini indah dan menarik untuk dikongsi bersama. Sekiranya terdapat mana-mana manusia yang enggan mengakui fitrah ini, mereka mestilah dididik dan diasuh untuk menerimanya. Manusia yang gagal memahami hikmah di sebalik kejadian fitrah ini akan mempunyai kecenderungan untuk mencipta konflik dan mewujudkan perselisihan faham dengan manusia yang berbeza dengannya.

Al-Quran juga menjelaskan bahawa semua manusia adalah makhluk yang diciptakan Allah dengan sebaik-baik ciptaan berbanding dengan makhluk-makhluk lain. Atas kapasiti ini maka semua manusia mempunyai kebebasan untuk hidup dan meneruskan kehidupan. Hak untuk hidup serta meneruskan kehidupan merupakan hak asasi setiap manusia. Menurut Ramadan dan Ahmad, hak tersebut tidak sedikitpun akan terhalang atau tercabut kerana berbezanya kepercayaan agama manusia. ${ }^{3}$ Hal ini bermaksud manusia tidak boleh mencipta sebarang undang-undang atau peraturan yang bertujuan untuk menyekat manusia lain yang berlainan agama untuk mengecap kebebasan dalam hidup. Jika perkara itu berlaku, maka berlakulah pencabulan ke atas hak-hak manusia yang asasi.

Malaysia ialah sebuah negara yang mempunyai masyarakat pelbagai budaya yang terdiri tidak kurang

3 Tariq Ramadan, The Messenger: The Meanings of the Life of Muhammad (London: Penguin Books Ltd., 2007), 89-90; Ahmad Sabri bin Osman, "Konsep Tauhid Menurut Ismail Raji al-Faruqi: Analisis Terhadap Isu-Isu Dalam Pluralisme Agama" (tesis PhD, Universiti Sains Malaysia, 2015), 342. 
daripada 40 suku etnik. Kebanyakan etnik ini boleh dikategorikan mengikut faktor-faktor seperti cara hidup, tempat tinggal, pekerjaan dan pendidikan. Dari segi agama pula, Islam ialah agama majoriti masyarakat di Malaysia dan menjadi agama rasmi persekutuan selain agama Buddha, Kristian, Hindu, Sikh, Konfusius dan Taoisme. ${ }^{4}$ Berdasarkan fakta itu, Malaysia ialah sebuah negara multietnik atau biasanya lebih dikenali dengan istilah multikaum.

Menurut Roff dan Warnk, pentadbiran kolonial British ialah yang paling awal mengemukakan fakta bahawa masyarakat di Malaysia telah dikategorikan kepada beberapa kaum utama yang berbeza. Akibatnya setiap kaum itu mula memperkenalkan dan mengembangkan identiti mereka yang tersendiri dan terpisah. Warisan sistem kolonial British itu kemudiannya telah diteruskan lagi dan diterima oleh masyarakat Malaysia pada zaman pasca kolonial sehingga akhirnya membentuk impak yang sangat mendalam terhadap senario politik kebangsaan dan kehidupan seharian. ${ }^{5}$

Lahirnya pelbagai agama, kepercayaan dan budaya itu melahirkan keanekaan pandangan. Setiap golongan masyarakat memang dipengaruhi oleh idea-idea yang telah sedia wujud dalam golongan mereka terhadap golongan lain. Idea ini mempengaruhi tindakan, perlakuan dan sikap mereka terhadap golongan lain. Di samping itu, sikap mereka terhadap golongan lain juga dipengaruhi oleh faktor sejarah dan keadaan semasa.

Sejarah di Malaysia telah menunjukkan bahawa telah berlaku segregasi kaum mengikut pekerjaan dan tempat tinggal. Kaum Melayu diletakkan di dalam penempatan

${ }^{4}$ Ruslan Zainuddin et.al., Kenegaraan Malaysia (Shah Alam: Penerbit Fajar Bakti, 2005), 31.

${ }^{5}$ William R. Roff, The Origins of Malay Nationalism (New Haven: Yale University Press, 1967), 67; Holger Warnk, "Race and Multiculturalism in Malaysia and Singapore", dalam The Newsletter, No. 55. IIAS, 2010. 
kampung dan majoritinya melakukan kerja di sawah dan kebun, kaum Cina diletakkan di dalam penempatan bandar dan menjadi peniaga dan berkerja di lombong, manakala kaum India pula diasingkan di dalam penempatan ladang getah dan berkerja di ladang itu.

Menurut Awang, walaupun keadaan seperti itu pada waktu sekarang dilihat agak kurang positif, namun daripada sudut keadaan semasa politik pada waktu itu, tindakan segregasi antara kaum tersebut dilihat sebagai sesuatu yang wajar. ${ }^{6}$ Di sebalik hakikat kepelbagaian itu, mengikut statistik yang dikeluarkan oleh Jabatan Statistik Malaysia, agama Islam masih menjadi agama terbesar iaitu dianuti oleh $61.3 \%$ penduduk di Malaysia. Diikuti oleh Buddha sebanyak 19.8\%, Kristian sebanyak 9.2\% dan Hindu pula sebanyak 6.3\%. Selebihnya menganut agama tradisi dan tidak menganut apa-apa agama. ${ }^{7}$

Pada hari ini, sudah ramai yang tahu bahawa agama Islam mengandungi ajaran-ajaran yang tidak pernah menolak hakikat wujudnya pelbagai agama dan hak untuk penganut agama-agama lain untuk komited dalam beragama. Sebelum ini ketika wacana pluraliti agama masih dibincangkan secara eksklusif oleh para sarjana di universiti, tidak ramai orang tahu bahawa agama Islam memiliki sifat ramah dan mahabbah kepada penganut agama lain.

Dalam konteks Islam di Malaysia, sifat ramah dan mahabbah itu sememangnya sudah wujud berdasarkan testimonial yang telah dikemukakan oleh beberapa sarjana. Sebagai contoh Esposito dan Voll. Mereka

6 Awang Hasmadi Awang Mois, "Hubungan Kaum dan Pencapaiannya," dalam Agenda Pembinaan Negara Bangsa Malaysia dalam Era Kebangkitan Asia, ed. Mohd Yaakob Hj Johari et.al. (Kota Kinabalu: Institut Kajian Pembangunan Sabah, 1997), 107.

7 Jabatan Perangkaan Malaysia, Taburan Penduduk dan Ciri-Ciri Asas Demografi (Kuala Lumpur: Jabatan Perangkaan Malaysia, 2010), 59. 
mengakui bahawa ruang selesa yang diberikan kepada penganut-penganut agama selain Islam untuk mengamalkan agama-agama mereka, membuktikan Islam di Malaysia ialah "moderate version of the religion". Pandangan yang sama juga diutarakan oleh Ros Aiza", Rahimin $^{10}$ dan Muhammadiris ${ }^{11}$ yang menyebut bahawa Islam meraikan sikap mahabbah ditambah pula dengan wujudnya sifat toleransi agama yang tinggi dalam sejarah Alam Melayu.

Satu perkara yang difikirkan juga perlu diberikan penjelasan di sini ialah hal yang berkaitan dengan istilah pluralisme dan pluraliti. Menurut pandangan Ahmad, pluralisme agama dan pluraliti agama merupakan dua perkara yang berbeza. Jika pluraliti agama berkaitan dengan fenomena agama yang majmuk, pluralisme agama pula berkaitan dengan falsafah di sebalik fenomena agama yang majmuk itu. ${ }^{12}$ Menurutnya lagi, pluralisme agama "mengambil berat tentang isu dakwaan kebenaran agama yang majmuk (plural truth claim)", ${ }^{13}$ malah pluralisme agama itu "masalah akidah kerana ia akan sampai kepada kesimpulan bahawa semua agama adalah sama."14

${ }^{8}$ John L. Esposito dan J. O. Voll, Islam and Democracy (New York: Oxford University Press, 1996); lihat juga A. Aziz dan S. A. Baharudin, "The Religious, the Plural, the Secular and the Modern: A Brief Critical Survey on Islam in Malaysia", Inter-Asia Cultural Studies 5(3) 2004: 341-357.

9 Ros Aiza Mohd Mokhtar dan Che Zarrina Sa'ari, "Konsep Sinkretisme Menurut Perspektif Islam,” Afkar 17 (2015), 73.

10 Rahimin Affandi Abd. Rahim, "Pendekatan Pluralisme dalam Pengajian Islam: Satu Pengenalan," Jurnal Peradaban 1 (2008), 9.

${ }^{11}$ Muhammadiris Duereh, "Analisis Liberalisme Agama di Malaysia Menurut Perspektif Akidah Islam" (tesis PhD, Universiti Sains Malaysia, 2013), 9-10.

${ }^{12}$ Ahmad Sabri, "Konsep Tauhid", 232.

${ }^{13}$ Ibid.

${ }^{14} \mathrm{Ibid}$. 
Pendapat yang sama juga dikemukakan oleh Muhammadiris. $^{15}$

Sebahagian intelektual Muslim seperti Ramadan, Budhy dan Rahimin tidak menggunakan definisi pluralisme agama seperti yang disebut di atas. Sebaliknya menganggap pluralisme agama itu ialah kepelbagaian agama yang menekankan aspek keterbukaan untuk menerima pandangan yang berbeza tanpa membuat penyamarataan antara setiap agama yang wujud. ${ }^{16}$

Dalam hal ini, penulis berpandangan bahawa memang benar Islam mempunyai sikap keterbukaan untuk meraikan agama-agama lain tetapi tidak sampai ke peringkat untuk menyamaratakan Islam dengan agamaagama lain itu. Jika telah sampai ke tahap menyamakan setiap agama, perkara itu dilihat sebagai sesuatu yang bertentangan dengan fitrah manusia kerana semua fundamentalis agama tidak setuju jika ajaran agama mereka disamakan dengan agama yang lain. Oleh itu, perkara yang tinggal hanyalah kedudukan istilah pluralisme agama itu dalam literatur.

Majoriti sarjana Islam menggunakan dan mengiktiraf istilah pluraliti atau kepelbagaian untuk merujuk kepada fenomena agama yang majmuk. ${ }^{17}$ Itulah istilah yang dianggap telah matang dan paling sesuai untuk menggambarkan realiti kepelbagaian agama. Malah menurut Ahmad, ${ }^{18}$ istilah pluralisme agama mesti dikaji melalui satu metodologi asas iaitu metodologi epistemologi Islam untuk mengelak kesalahfahaman. Hasil kajian beliau mendapati bahawa istilah pluraliti ialah

\footnotetext{
${ }^{15}$ Muhammadiris, “Analisis Liberalisme”, 97.

16 Tariq Ramadan, Western Muslims and the Future of Islam (New York: Oxford University Press, 2004), 201-202; Budhy Munawar Rachman, Islam Pluralis: Wacana Kesetaraan Kaum Beriman (Jakarta: Penerbit Paramadina, 2002), 31; Rahimin, "Pluralisme", 5.

17 Ahmad, "Konsep Tauhid", 215.

${ }^{18}$ Ibid., 216.
} 
lebih tepat dan sesuai berbanding pluralisme. ${ }^{19}$ Justeru, untuk tidak mengundang sebarang kekeliruan dalam artikel ini, penulis memilih untuk menggunakan istilah pluraliti yang merujuk kepada fenomena kepelbagaian agama.

Berhubung dengan sikap toleransi dan keterbukaan dalam berinteraksi dengan orang yang bukan Islam, jika dilihat di dalam al-Quran, terdapat beberapa ayat yang boleh dijadikan bukti wujudnya pengiktirafan tersebut. Walau bagaimanapun, pengiktirafan ini hanyalah tentang kewujudan agama-agama itu sahaja, bukan bermaksud pengiktirafan tentang kebenaran agama-agama itu. ${ }^{20}$ Sebagai contoh ayat-ayat itu seperti berikut:

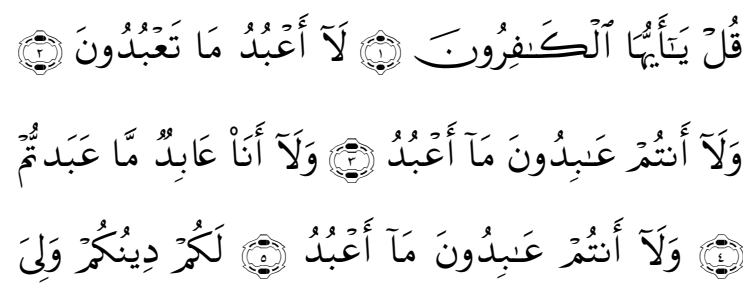

دِين

Terjemahan: Katakanlah wahai orang-orang kafir; aku tidak akan menyembah apa yang kamu sembah; dan kamu bukan penyembah apa yang aku sembah; dan tidak aku penyembah apa yang kamu sembah; dan tidak kamu penyembah apa yang aku sembah; untuk kamu agama kamu dan untuk aku agamaku.

Al-Kafirun 109:1-6

\footnotetext{
${ }^{19}$ Ibid.

${ }^{20}$ Ibid., 210; Muhammadiris Duereh, "Analisis Liberalisme”, 95.
} 


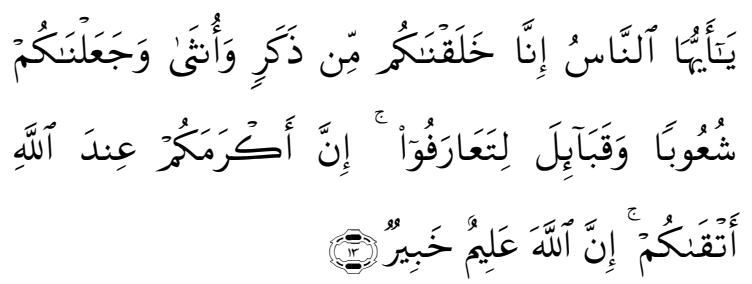

Terjemahan: Wahai manusia sesungguhnya kami menciptakan kamu dari seorang lelaki dan seorang perempuan dan menjadikan kamu berbangsa-bangsa dan bersuku-suku supaya kamu saling mengenali. Sesungguhnya orang yang paling mulia dalam kalangan kamu pada sisi Allah ialah orang yang paling bertaqwa dalam kalangan kamu. Sesungguhnya Allah Maha Mengetahui lagi Maha Mengenali.

Al-Hujurat 49:13

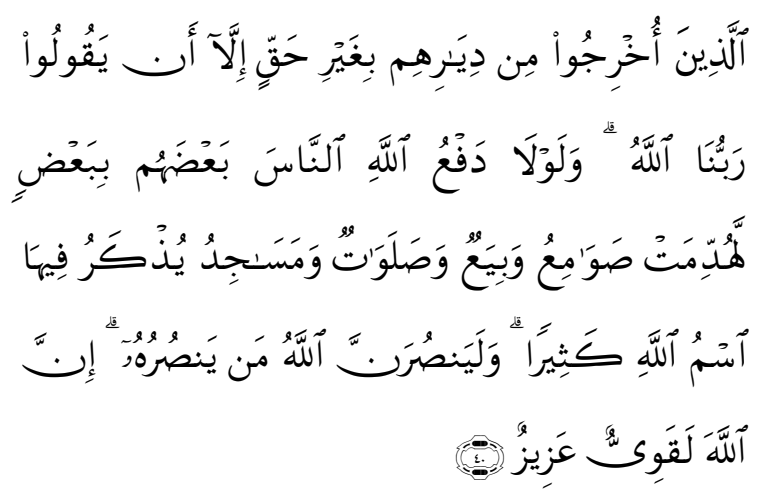

Terjemahan: Orang-orang yang telah diusir dari kampung halaman mereka tanpa alasan yang benar, kecuali mereka berkata: "Tuhan kami Allah"; dan sekiranya Allah tiada menolak sebahagian manusia dengan sebahagian manusia yang lain, tentulah telah dirobohkan gereja-gereja, rumah-rumah ibadat dan masjid- masjid yang di dalamnya banyak 
disebut nama Allah. Sesungguhnya Allah pasti menolong orang yang menolongNya. Sesungguhnya Allah benar-benar Maha Kuat lagi Maha Perkasa.

Al-Hajj 22:40
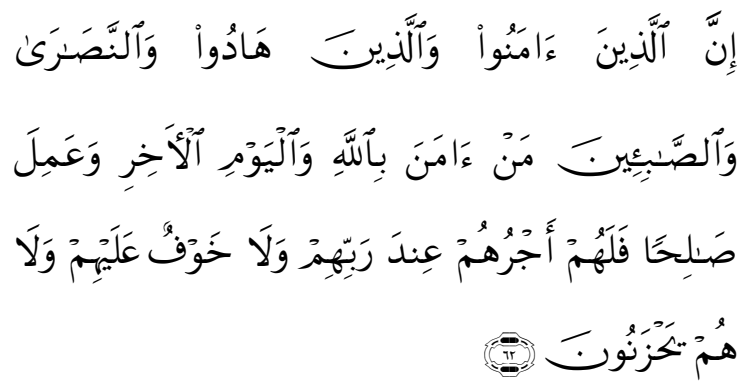

Terjemahan: Sesungguhnya orang-orang yang beriman dan orang-orang Yahudi dan orangorang Nasrani dan orang-orang Sabi'in, siapa yang beriman kepada Allah dan hari Akhirat dan melakukan amal saleh, maka untuk mereka pahala pada sisi Tuhan mereka dan tidak ada kekhuatiran ke atas mereka, dan tidak mereka bersedih hati.

\section{Al-Baqarah 2:62}

Oleh sebab soal agama dan kepercayaan menjadi agenda yang sangat penting dalam kehidupan manusia, maka aspek komitmen dan persefahaman antara agama harus sentiasa diberi prioriti. Hal ini sangat penting kepada setiap penganut agama yang komited di seluruh dunia, terutamanya di Malaysia, sebuah negara yang mempunyai penduduk berbilang agama dan kaum. Dalam konteks ini, perlu dijelaskan apakah yang dimaksudkan dengan komitmen dan persefahaman dalam konteks agama. 
Penulis bersetuju dengan Kamar $^{21}$ dan Hikmawati ${ }^{22}$ bahawa maksud komitmen dalam agama ialah kesungguhan seorang itu untuk benar-benar memahami agama kepercayaannya. Serta bersikap setia dan taat kepada setiap ajaran yang terkandung dalam agama itu. Manakala hal yang dimaksudkan dengan persefahaman pula ialah menghormati dan membenarkan penganut agama lain juga mempamerkan komitmen kepada agama mereka masing-masing. ${ }^{23}$ Persefahaman ini juga bermaksud seorang itu tidak harus memaksa orang lain untuk menerima sesuatu yang tidak boleh diterima atau bertentangan dengan ajaran, sistem kepercayaan dan nilainilai yang terkandung dalam agama mereka. Termasuklah juga seorang itu tidak boleh memaksa orang lain mengubah, meminda dan menokok tambah ajaran-ajaran yang terdapat dalam agama mereka.

Itulah dua aspek yang perlu didokong iaitu komitmen dan persefahaman perlu diamalkan dan dipertahankan oleh setiap rakyat Malaysia. Sebagai sebuah negara yang mempunyai rakyat berbilang agama dan kaum, tentulah cabarannya menjadi lebih rumit. Cabaran yang dimaksudkan ini ialah cabaran untuk mewujudkan perpaduan kaum dan agama. ${ }^{24}$ Jika cabaran-cabaran itu tidak ditangani dengan cara yang sewajarnya, tentulah akan berlaku pelbagai masalah dan kesusahan nanti.

${ }^{21}$ Kamar Oniah Kamaruzaman, Religion And Pluralistic Co-Exixtence: The Muhibah Perspective (A Collection of Seminar Papers) (Kuala Lumpur: IIUM Press, 2010), 14.

${ }^{22}$ Fenti Hikmawati, "Psychoeducation of Character Personal's Local Wisdom of Sundanese People's Behaviour in Interternalizing Religious Commitment," Tarbiya: Journal of Education in Muslim Society 3(1) 2016, 64.

${ }^{23}$ Menurut Tariq Ramadan, persefahaman sebegini akan lebih berjaya jika semua pihak yang terlibat menghayati tiga syarat yang asasi, iaitu ilmu; kejujuran; dan tawaduk. Lihat Tariq Ramadan, The Messenger, 117.

${ }^{24}$ Rahimin Affandi Abd. Rahim et.al., "Dialog Antara Agama: Realiti dan Prospek di Malaysia," Kajian Malaysia 29(2) 2011, 88. 


\section{Interaksi Agama dan Kaum di Malaysia}

Proses interaksi antara agama dan kaum di Malaysia telah banyak mengalami perkembangan dalam tempoh lima dekad lalu. Berdasarkan penelitian Chandra Muzaffar, isuisu kaum di Malaysia boleh dibahagikan kepada beberapa peringkat. Pada tahun 1950-an, isu kewarganegaraan dan kontrak sosial mendominasi hubungan kaum, diikuti dengan isu bahasa pada tahun 1960-an sebelum pelaksanaan Dasar Ekonomi Baru (DEB), manakala kuota dan urbanisasi mencorakkan hubungan etnik pada tahun 1970-an dan 1980-an. Pada tahun 1990-an dan hingga sekarang, barulah isu-isu agama menjadi dominan dalam mempengaruhi hubungan antara masyarakat di negara ini. Malah, jika dibuat perbandingan dengan isu-isu sebelumnya, isu agama yang muncul ini begitu signifikan kesannya $^{25}$.

Sebagai contoh, melalui statistik yang dikeluarkan oleh Jabatan Perpaduan Negara dan Integrasi Nasional, terdapat 223 kes yang dilaporkan berkaitan dengan konflik sosial dari tahun 1996 hingga 2002. Melalui Jadual 1, pergaduhan antara kaum ialah paling tinggi iaitu sebanyak 81 kes, diikuti 65 konflik agama, 38 konflik keselamatan dan lain-lain. Kebanyakan pergaduhan antara kaum yang berlaku melibatkan pelajar-pelajar sekolah yang mempunyai masalah sikap dan disiplin.

Jadual 1: Konflik Sosial 1996-2002

\begin{tabular}{|l|c|c|c|c|c|c|c|c|}
\hline \multicolumn{1}{|c|}{ Konflik } & $\mathbf{1 9 9 6}$ & $\mathbf{1 9 9 7}$ & $\mathbf{1 9 9 8}$ & $\mathbf{1 9 9 9}$ & $\mathbf{2 0 0 0}$ & $\mathbf{2 0 0 1}$ & $\mathbf{2 0 0 2}$ & Jumlah \\
\hline Agama & 7 & 2 & 25 & 11 & 8 & 9 & 3 & 65 \\
\hline $\begin{array}{l}\text { Pergaduhan } \\
\text { Kaum }\end{array}$ & 12 & 4 & 10 & 5 & 8 & 28 & 14 & 81 \\
\hline $\begin{array}{l}\text { Gangguan } \\
\text { Awam }\end{array}$ & 0 & 0 & 4 & 2 & 2 & 1 & 1 & 10 \\
\hline
\end{tabular}

${ }^{25}$ Chandra Muzaffar, "Islam and the Future of Inter-Ethnic Relations in Malaysia," dalam Occasional Paper Series 1 (Kuala Lumpur: International Institute of Advanced Islamic Studies (IAIS) Malaysia, t.t.), 5-8. 
Mohd Farid \& Khadijah, "Respons Pelajar IPTA terhadap Pluraliti Agama di Malaysia," Afkār Vol. 19 Issue 1 (2017): 1-40

\begin{tabular}{|l|c|c|c|c|c|c|c|c|}
\hline Pembunuhan & 0 & 1 & 0 & 0 & 0 & 0 & 0 & 1 \\
\hline Keselamatan & 6 & 0 & 1 & 7 & 6 & 17 & 1 & 38 \\
\hline Perkauman & 2 & 2 & 1 & 1 & 1 & 0 & 0 & 7 \\
\hline Ekonomi & 0 & 0 & 4 & 0 & 1 & 2 & 1 & 8 \\
\hline Kejiranan & 3 & 3 & 0 & 0 & 0 & 3 & 0 & 9 \\
\hline Setinggan & 0 & 0 & 0 & 0 & 0 & 0 & 3 & 3 \\
\hline Lain-lain & 0 & 0 & 0 & 0 & 0 & 0 & 1 & 1 \\
\hline \multicolumn{1}{|c|}{ Jumlah } & 30 & 12 & 45 & 26 & 26 & 60 & 24 & 223 \\
\hline
\end{tabular}

Sumber: Azman Amin Hassan, "Solving conflicts in a multicultural society: The case of Kampung Medan," dalam Reading on Ethnic Relations in a Multicultural Society, disunting oleh Muhammad Kamarul Kabilan dan Zaharah Hassan (Serdang: Penerbit UPM, 2005).

Dalam landskap sosio-politik negara, terdapat pelbagai sejarah hitam yang telah berlaku melibatkan konflik keagamaan dan perkauman. Insiden yang paling buruk pernah digambarkan berlaku dalam sejarah negara ialah seperti insiden rusuhan kaum pada tahun 1969. Insiden itu menyebabkan negara diisytiharkan darurat dan diperintah oleh Majlis Gerakan Negara selama 20 bulan. ${ }^{26}$ Diikuti dengan peristiwa Kampung Rawa pada tahun 1997, insiden pergaduhan beramai-ramai pada tahun 2001 di Petaling Jaya Selatan. Dalam peristiwa ini, enam orang meninggal dunia dan 44 orang telah cedera. Selain itu ialah insiden Kampung Medan pada tahun 2001 dan peristiwa kecil seperti isu perarakan kepala lembu di Selangor dan meletakkan kepala khinzir dalam masjid di Kuala Lumpur. ${ }^{27}$

Selain daripada insiden yang melibatkan kekerasan fizikal seperti di atas, berlaku juga peristiwa yang berbentuk hasutan dan provokasi. Sebagai contoh, tindakan Malaysian Consultative Council of Buddhism,

26 Nurazuki Yusuff, "Pengalaman Konflik Hubungan Etnik di Malaysia: Satu Sorotan," dalam Islam dan Hubungan Etnik: Perbincangan Isu-Isu Semasa, ed. Alis Putih (Jitra: Pure Honey Enterprise, 2008), 71.

${ }^{27}$ Rahimin Affandi, "Dialog", 88. 
Christianity, Hinduism dan Sikhism (MCCBCHS) yang mencampuri isu politik apabila membantah cadangan Parti Islam Se-Malaysia (PAS) untuk melaksanakan undangundang hudud di Kelantan. Termasuklah beberapa aktivis bukan Islam yang turut membantah dengan keras cadangan PAS untuk membentangkan akta kawal propaganda agama bukan Islam di Malaysia. Sesuatu yang mereka sifatkan sebagai tidak boleh diterima, tidak demokratik dan bertentangan dengan Perlembagaan Malaysia. ${ }^{28}$

Isu yang membabitkan penggunaan kalimah "Allah" turut mewarnai senario konflik dalam interaksi antara agama dan kaum. Polemik itu didakwa telah berlaku sejak tahun 80an lagi apabila dalam mesyuarat Kabinet bertarikh 16 Mei 1986 telah memutuskan larangan kepada golongan bukan Islam daripada menggunakan kalimah Allah. Pada waktu itu, walaupun larangan itu pada asasnya kurang dipersetujui oleh mereka, namun tiada isu yang telah dibangkitkan untuk menyuarakan ketidakpuasan hati. Sehinggalah pada 31 Disember 2007, pengarang akhbar Herald-The Catholic Weekly, Paderi Lawrence Andrew membuat kenyataan bahawa pihak Kementerian Dalam Negeri (KDN) memperbaharui permit penerbitan akhbar itu tanpa menyatakan larangan kepada mereka daripada menggunakan kalimah Allah dalam akhbar mereka.

Walau bagaimanapun, tidak sampai seminggu kenyataan itu dikeluarkan, Kabinet telah membuat keputusan untuk mengekalkan larangan bagi semua agama kecuali Islam daripada menggunakan kalimah Allah. Keputusan itu membatalkan keizinan yang didakwa oleh Andrew telahpun diberikan sebelumnya oleh KDN. Pada kali ini, pihak Gereja Katolik menyuarakan suara tidak puas hati dengan memfailkan permohonan di Mahkamah Tinggi pada 19 Mac 2008. Andrew yang mewakili gereja itu meminta pihak mahkamah melakukan semakan semula

${ }^{28}$ Ibid., 92. 
terhadap keputusan yang dibuat oleh Kabinet. Kes itu kemudiannya diterima oleh Mahkamah Tinggi (Bahagian Rayuan dan Kuasa-Kuasa Khas) pada 5 Mei 2008 dan membenarkan permohonan Gereja Katolik untuk membuat semakan kehakiman terhadap keputusan Kabinet itu. ${ }^{29}$

Tidak terkecuali ialah provokasi yang dicetuskan oleh penganut agama Islam sendiri. Terdapat sesetengah golongan yang membantah dengan lantang dialog agama ${ }^{30}$ serta menuduh aktiviti itu mempunyai kecenderungan untuk mempromosi pluralisme agama dan akan memberi kesan yang negatif kepada penganut agama Islam. Hal ini dianggap seperti mengkhianati dan menyinggung sensitiviti penganut agama Islam. ${ }^{31}$

Menurut Zaid Ahmad, masalah yang dihadapi oleh masyarakat berbilang agama dan kaum seperti di negara ini ialah perpaduan dan integrasi nasional. Masalah ini boleh dilihat melalui dua perspektif: pertama ialah konflik dalaman antara kaum-kaum itu sendiri; kedua ialah konflik antara kaum-kaum yang berlainan. Namun, konflik dalaman antara sesama kaum tidak seserius konflik antara kaum yang berbeza. ${ }^{32}$

${ }^{29}$ Mohd Aizam Mas'od, "Hujah Menolak Penggunaan Kalimah 'Allah' oleh Kristian”, Jurnal Penyelidikan Islam 21 (2008), 1-8.

30 Dalam konteks ini, dialog yang dimaksudkan ialah perbualan, perbincangan, perundingan dan pertukaran idea dan pendapat untuk mendapatkan kesahihan maklumat dan justifikasi hujah daripada setiap pihak yang terlibat di dalamnya. Lihat Leonard Swidler, "Dialogue in Malaysia and the Global Scenario," dalam Civilisational Dialogue Centre of Monograph Series, No. 1. (Kuala Lumpur: Universiti Malaya, 2003), 8.

31 Ibid., 95.

32 Zaid Ahmad, Cabaran Hubungan Etnik di Malaysia dan Global dalam Hubungan Etnik di Malaysia (Shah Alam: Oxford Fajar, 2006), 42. 


\section{Tinjauan Terhadap Beberapa Kajian Pluraliti Agama}

Antara kajian tentang pluraliti agama ialah dalam tesis kedoktoran falsafah oleh Haslina Ibrahim. Tesis itu berjudul "Diversity of Religions: An Assessment of the Christian and Muslim Encounters with the Philosophy of Religious Pluralism". ${ }^{33}$ Beliau telah meletakkan beberapa tokoh seperti Ismail Raji al-Faruqi, Fazlur Rahman dan Seyyed Hossein Nasr sebagai tokoh yang mempunyai pemikiran plural.

Pemilihan Haslina terhadap al-Faruqi sebagai mewakili pemikir Islam yang berciri plural adalah berdasarkan kedudukan dan penglibatan al-Faruqi yang serius dalam dialog antara agama. Dalam tesis tersebut, Haslina membawa beberapa konsep yang digagaskan oleh al-Faruqi yang dianalisis oleh beliau sebagai bergema pluralisme dan bukannya pluraliti. Konsep-konsep tersebut antaranya ialah konsep Meta-religion, Din alFitrah, Abrahamic Traditions dan fenomena kerasulan. Namun, Haslina menegaskan bahawa idea al-Faruqi pada hakikatnya tidak pernah lari daripada paradigma tauhid.

Anis Malik Thoha dalam buku beliau Tren Pluralisme Agama: Tinjauan Kritis meninjau tentang aliran-aliran pluralisme agama dan dasar-dasarnya. ${ }^{34}$ Beliau membahagikan aliran pluralisme agama kepada empat kategori iaitu Humanisme Sekular, Teologi Global, Sinkretisme dan Hikmah Abadi. Dalam aliran Teologi Global, Anis menganalisis secara ilmiah pemikiran W. C. Smith yang mengemukakan gagasan penilaian semula terminologi agama. Di dalam buku ini, Anis banyak memetik pandangan al-Faruqi apabila membahaskan tentang tinjauan Islam terhadap fenomena dan aliran-

33 Haslina Ibrahim, "Diversity of Religions: An Assessment of the Christian and Muslim Encounters with the Philosophy of Religious Pluralism," (tesis PhD, Universiti Islam Antarabangsa Malaysia, 2005).

${ }^{34}$ Anis Malik Thoha, Tren Pluralisme Agama: Tinjauan Kritis (Jakarta: Gema Insani, 2005). 
aliran pluralisme agama. Dasar ini merupakan teras ajaran Islam yang membezakannya dengan agama-agama lain di mana seluruh aspek hidup manusia itu berpaksikan kalimah ini. Melalui pemusatan tauhid ini, Islam mengajar umatnya tentang hakikat tuhan, hakikat wahyu, hakikat manusia dan hakikat masyarakat kerana keempat-empat hakikat ini secara ontologinya berkait dengan agamaagama lain.

Kajian mengenai multi etnik dan pluraliti agama di Malaysia telah disentuh oleh beberapa penulis. Terdapat satu buku yang disunting oleh Daniel P.S. Goh berjudul Race and Multiculturalism in Malaysia and Singapore memuatkan sebelas esei. ${ }^{35}$ Buku ini mengemukakan kesarjanaan kritis yang baik dalam kajian berkenaan multi etnik dan pluraliti. Dalam esei yang ditulis oleh Gaik Cheng $\mathrm{Khoo}^{36}$, beliau menganalisa filem-filem yang dihasilkan oleh Yasmin Ahmad, seorang bekas pengarah filem tempatan. Skop analisa beliau ialah tentang elemenelemen 'kemelayuan' yang terdapat dalam filem-filem Yasmin. Sebelum meninggal dunia, bekas pengarah filem yang berbakat ini sempat menghasilkan enam buah filem yang sebahagian besarnya bertemakan isu multi etnik dan agama.

Menurut Gaik, filem-filem Yasmin tidak begitu digemari oleh sebahagian besar pengkritik filem tempatan, pihak agamawan dan intelektual kerana filem-filemnya mengemukakan kritik-kritik terhadap kesubjektifan 'Melayu' dan tanggapan stereotaip tentang gender. Selain

35 Daniel P.S. Goh, Matilda Gabrielpillai, Philip Holden dan Gaik Cheng Khoo, eds, Race and Multiculturalism in Malaysia and Singapore (London: Routledge, 2009).

${ }^{36}$ Gaik Cheng Khoo, "Reading the Films of Independent Filmmaker Yasmin Ahmad: Cosmopolitanism, Sufi Islam and Malay Subjectivity," dalam Race and Multiculturalism in Malaysia and Singapore, ed. Daniel P.S. Goh et.al. (London: Routledge, 2009), 107-123. 
itu, dalam esei yang lain, Helen Ting ${ }^{37}$ menulis tentang pengaruh 'kemelayuan' dan legitimasi ketuanan Melayu di dalam buku-buku teks sekolah yang digunapakai di Malaysia.

Secara keseluruhannya, esei-esei yang dimuatkan dalam buku ini cuba memberikan gambaran tentang bentuk-bentuk perbincangan yang sering ditimbulkan oleh golongan minoriti atau bukan Melayu di Malaysia. Malah dalam kesimpulan yang dibuat oleh Daniel, beliau berpandangan bahawa bukanlah satu perkara yang mengejutkan jika isu-isu tentang multi etnik, budaya dan agama di Malaysia sering diketepikan oleh orang Melayu, tetapi menarik minat pula penulis-penulis bukan Melayu. Semuanya dikaitkan dengan identiti orang Melayu sebagai penduduk asal di Malaysia dan mereka dijamin kedudukan yang istimewa, satu hak keistimewaan yang dianggap oleh Daniel mendorong berlakunya cauvinisme terhadap sesama Melayu. Inilah isu yang menjadi tema utama dalam buku tersebut.

Kajian Kamar Oniah Kamaruzaman pula ialah tentang konsep muhibbah dan toleransi antara penganut agama yang berbeza. ${ }^{38}$ Beliau membuat perbezaan antara muhibah dan toleransi. Istilah yang paling sesuai, menurut beliau ialah muhibah kerana istilah itu menggambarkan semangat kasih dan sayang yang perlu wujud dalam masyarakat. Manakala istilah toleransi tidak memberi maksud yang begitu harmoni. Toleransi ialah satu sifat yang mengandungi elemen-elemen tolak ansur antara dua pihak, membayangkan satu keadaan wujudnya hubungan antara satu pihak dengan satu pihak lagi yang berada pada peringkat yang lebih bawah. Beliau menjelaskan bahawa

37 Helen Ting, "Malaysian History Textbooks and the Discourse of Ketuanan Melayu," dalam Race and Multiculturalism in Malaysia and Singapore, ed. Daniel P.S. Goh et.al. (London: Routledge, 2009), 107-123.

${ }^{38}$ Kamar Oniah, Religion, 14. 
toleransi ini sentiasa akan mewujudkan satu senario iaitu pihak yang di bawah itulah yang perlu bertolak ansur. Sementara pihak yang satu lagi itu boleh memilih untuk bertolak ansur atau tidak.

Kajian oleh Rahimin Affandi Abd Rahim pula berkisar tentang prospek dialog antara agama dalam konteks masyarakat plural di Malaysia. $^{39}$ Beliau berpandangan, jambatan untuk membina keharmonian antara kaum dalam konteks di Malaysia ialah melalui dialog antara agama. Namun, menurut beliau aktiviti dialog yang telah berlangsung sebelum ini mempunyai kelemahan. Hal itu perlu diperbaiki oleh semua pihak yang terlibat di dalam dialog itu. Oleh sebab Islam telah meletakkan prinsip yang kukuh terhadap dialog agama, maka kegagalan pihak yang terlibat dalam dialog antara agama untuk memperbaiki kaedah diskusinya akan menyebabkan prospek dialog antara agama akan menjadi suram dan membentuk tembok pemisah antara masyarakat plural di Malaysia.

Seterusnya dalam buku yang ditulis oleh Mohd Farid Mohd Sharif pula, beliau mengemukakan konsep berkongsi rasa. $^{40}$ Maksud kongsi rasa ialah konsep kesepakatan dan kesediaan antara setiap penganut agama yang berbeza untuk melaksanakan sesuatu program yang bermanfaat kepada semua dengan perasaan penuh ikhlas dan jujur terhadap sesuatu yang dilakukan. Buku itu juga menekankan bahawa konsep kongsi rasa bukan sahaja meraikan aspek-aspek kemanusiaan, malah mengutamakan nilai-nilai kebersamaan dan meletakkannya pada kedudukan yang mulia. Selain itu, kongsi rasa itu juga menitikberatkan kesamarataan individu sebagai satu warganegara malah sentiasa menghormati kepercayaan, keyakinan dan pandangan

\footnotetext{
${ }^{39}$ Rahimin Affandi Abd. Rahim et.al. "Dialog".

${ }^{40}$ Mohd Farid Mohd Sharif, Maaf...Tuhan Kita Tidak Sama: Mengulas Isu Interaksi Agama di Malaysia (Jitra: Bitara Media, 2012).
} 
orang lain asalkan saja semua itu masih berada dalam lingkungan kesopanan dan undang-undang.

Oleh itu, kongsi rasa yang dicadangkan oleh beliau dalam buku itu, ialah untuk memberitahu orang ramai bahawa fokusnya tidak hanya kepada dialog, malah menuntut setiap orang bertindak dalam bentuk yang lebih praktikal. Sesuai dengan tanggungjawab setiap orang sebagai anggota masyarakat yang mempunyai kewajipan untuk memberi sumbangan kepada pembinaan sebuah negara bangsa. Dalam erti kata lain, kongsi rasa bukan sahaja meraikan aspek-aspek ta ‘āwun (tolong-menolong) yang dianjurkan oleh agama Islam, tetapi juga konsep kemasyarakatan yang menempatkan orang itu betul-betul berada di tengah-tengah masyarakat yang saling mahu menghormati, menerima dan memberi.

\section{Rasional Pemilihan Pelajar Institut Pengajian Tinggi Awam (IPTA)}

Maklumat yang dikemukakan dalam bahagian ini berbentuk deskriptif tentang respons dalam kalangan pelajar di IPTA. Menurut Wiersma kaedah penyampaian maklumat dalam bentuk deskriptif ini merupakan antara kaedah yang baik jika maklumat tersebut digunakan untuk mengukur atau menilai sikap, persepsi dan pencapaian sesuatu program. ${ }^{41}$ Selain itu, bentuk deskriptif ini juga sesuai dengan keperluan laporan iaitu untuk melihat suatu fenomena yang berlaku. ${ }^{42}$ Satu set soal selidik disediakan bagi tujuan tersebut yang dibina sendiri oleh penulis untuk mengumpul maklumat yang diperlukan. Menurut Tuckman instrumen soal selidik merupakan cara yang baik untuk mendapatkan maklumat daripada responden. ${ }^{43}$

41 W. Wiersma, Research Methods in Education: An Introduction (Boston Allyn and Bacon, 1995), 33.

42 Mohd Majid Konting, Kaedah Penyelidikan Pendidikan (Kuala Lumpur: Dewan Bahasa dan Pustaka, 1990), 25.

43 B.W. Tuckman, Conducting Educational Research (Fort Worth: Harcourt Brace College Publishers, 1999), 41. 
Populasi subjek ini ialah semua pelajar tahun tiga di empat IPTA yang terpilih iaitu Universiti Malaya (UM), Universiti Sains Malaysia (USM), Universiti Kebangsaan Malaysia (UKM) dan Universiti Putra Malaysia (UPM). Pemilihan pelajar dari UM, UKM dan UPM dibuat kerana mereka terdedah kepada kepelbagaian kaum dan agama. Di samping itu, ketiga-tiga IPTA itu terletak di Lembah Klang yang menggambarkan nisbah kependudukan Malaysia serta bilangan pelajar yang terdiri daripada pelbagai agama. Walaupun USM tidak terletak di Lembah Kelang, namun USM juga mempunyai ciri-ciri yang sama dengan UM, UKM dan UPM.

Selain itu, keempat-empat universiti tersebut adalah universiti yang paling awal ditubuhkan dan tersenarai dalam kelompok Universiti Penyelidikan di Malaysia. Situasi itu dilihat memberi kesan kepada pengorganisasian persatuan-persatuan pelajar berbanding universiti awam yang baru. Selain itu, keempat-empat universiti itu sentiasa menjadi pilihan utama pelajar dalam kemasukan ke IPTA. Keadaan ini sangat signifikan dan relevan kepada persepsi pelajar dalam sesuatu isu khususnya yang melibatkan isu pluralisme agama.

Pemilihan sampel pula dibuat melalui kaedah persampelan berkelompok. Persampelan berkelompok boleh digunakan dengan menentukan bilangan kelompok seperti mengikut negeri, daerah atau mukim. Pemilihan melalui cara ini sesuai jika populasi besar dan bertaburan di merata tempat. Di samping dapat menjimatkan masa serta mengurangkan pelbagai masalah kerana pengkaji mengelompokkan sampel dalam satu kelompok sebelum pemilihan secara rawak dilakukan. Untuk menentukan bilangan responden, Jadual Penentuan Saiz Sampel Krejcie dan Morgan telah digunakan. ${ }^{44}$ Berikut ialah

44 R. V. Krejcie \& D. W. Morgan, "Determining Sample Size for Research Activities," Educational and Psychology Measurement, 30:3 (1970), 11. 
jadual bilangan pelajar tahun tiga di empat IPTA sesi 2011/2012:

Jadual 2: Bilangan Pelajar Tahun Tiga di Empat IPTA Sesi 2011/2012

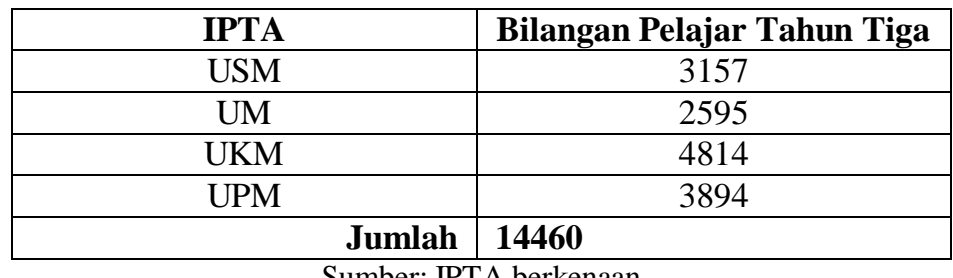

Berdasarkan populasi pelajar di empat IPTA seperti dinyatakan dalam Jadual 2, saiz sampel yang diperlukan ialah 800. Menurut Sidek Mohd Noah, semakin besar saiz sampel semakin kecil ralat persampelan. ${ }^{45}$ Bagi memastikan setiap agama diwakili, maka persampelan rawak strata digunakan dengan nisbah mengikut agama Islam, Buddha, Kristian dan Hindu iaitu 50:30:10:10 dan seramai 800 pelajar akan dijadikan responden.

Instrumen yang digunakan untuk pengumpulan data ialah satu set soal selidik. Menurut Tuckman, bahawa soal selidik dan temu bual merupakan dua bentuk instrumen yang berkesan bagi memperolehi maklumat daripada responden selain membuat pemerhatian. ${ }^{46}$ Semua soalan yang dimasukkan dalam set soal selidik berbentuk positif dan responden dikehendaki menyatakan persepsi mereka mengikut skala likert. Soal selidik terdiri daripada dua bahagian iaitu Bahagian A dan B. Bahagian A berkaitan dengan demografi responden. Bahagian $\mathrm{B}$ mengenai respons pelajar terhadap pluralisme agama.

Aspek kesahan soalan dalam soal selidik yang telah dibina itu juga diberikan perhatian yang wajar. Seramai empat orang pakar telah menyemak soalan-soalan dalam

\footnotetext{
45 Sidek Mohd Noah, Reka Bentuk Penyelidikan: Falsafah, Teori dan Praktis (Serdang: Penerbit UPM, 2002), 23.

${ }^{46}$ Tuckman, Conducting Educational Research, 41.
} 
set soal selidik yang terdiri daripada dua pakar dalam bidang perbandingan agama, seorang pakar dalam bidang penyelidikan hubungan kaum dan seorang lagi pakar dalam kaedah pembinaan soal selidik. Kebolehpercayaan merujuk kepada kestabilan dan ketekalan dalam instrumen dalam mengukur sesuatu konsep. Ujian yang popular dan selalu digunakan dalam mengukur ketekalan dalam sesuatu konsep ialah Alpha Cronbach. Nilai kebolehpercayan Alpha Cronbach adalah antara 0.0 hingga 1.0. Menurut Mohd Majid Konting, nilai Alpha Cronbach melebihi 0.60 sering digunapakai sebagai indeks kebolehpercayaan dalam sesuatu penyelidikan. ${ }^{47}$

Oleh itu, dalam instrumen soal selidik ini, penulis telah menetapkan nilai Alpha Cronbach melebihi 0.60 sebagai nilai kebolehpercayaan kepada setiap bahagian soal selidik yang diuji. Selanjutnya, untuk menentukan nilai kebolehpercayaan bagi soal selidik yang disediakan, sebuah kajian rintis telah terlebih dahulu dilaksanakan.

Kajian rintis dilakukan bertujuan untuk mengenal pasti kelemahan dan kekuatan yang terdapat dalam soal selidik. Sebelum soal selidik diedarkan, 50 orang pelajar telah dipilih untuk menjawab soal selidik ini terlebih dahulu. Hasil kajian menunjukkan 50 orang pelajar tersebut tidak mempunyai masalah untuk memahami soalan dan tidak bertanya apa yang dikehendaki oleh soalan tersebut.

Selanjutnya, dengan menggunakan program Statistical Package for the Social Science (SPSS), penulis telah mengira nilai kebolehpercayaan dan nilai Alpha Cronbach. Nilai Alpha Cronbach yang diperolehi bagi kesemua item soalan adalah melebihi 0.6. Oleh itu, soal selidik yang dibina untuk tujuan ini didapati sesuai untuk digunakan. Data yang diperolehi kemudian dianalisis dengan menggunakan program SPSS versi 16 melalui min, sisihan piawai, Chi square dan statistik jadual silang

${ }^{47}$ Mohd Majid Konting, Kaedah Penyelidikan Pendidikan, 26. 
(cross-tabulation). Statistik deskriptif seperti frekuensi, peratusan, purata skor atau min, statistik jadual silang dan correlation coefficient digunakan bagi menerangkan latar belakang responden dan menganalisis persepsi pelajar tentang pluralisme agama dalam konteks masyarakat plural di Malaysia.

Seperti yang telah disebutkan oleh penulis sebelum ini responden ialah dalam kalangan pelajar tahun tiga daripada empat buah IPTA iaitu USM, UM, UKM dan UPM. Seramai 800 pelajar telah menjawab soal selidik yang diedarkan. Latar belakang responden ditanya dalam Bahagian A. Latar belakang responden akan dibahagikan kepada tiga bahagian, iaitu profil, latar belakang akademik dan tempat tinggal responden. Jadual 3 memaparkan maklumat mengenai responden. Daripada seramai 800 orang responden, seramai 550 orang $(69 \%)$ adalah pelajar perempuan, manakala pelajar lelaki seramai 250 orang (31\%). Daripada sudut agama anutan, seramai 486 orang $(60.5 \%)$ adalah daripada agama Islam, diikuti oleh seramai 187 orang $(23.4 \%)$ beragama Buddha, manakala responden daripada agama Kristian dan Hindu, masingmasing seramai 52 orang $(6.5 \%)$ dan 68 orang $(8.5 \%)$.

Jadual 3: Profil Responden

\begin{tabular}{|l|ll|}
\hline \multicolumn{1}{|c|}{$n=800$} & \multicolumn{2}{|c|}{ Bilangan dan Peratusan } \\
\hline Jantina: & & \\
Lelaki & 250 & $(31.0 \%)$ \\
Perempuan & 550 & $(69.0 \%)$ \\
\hline Agama: & & \\
Islam & 486 & $(60.5 \%)$ \\
Buddha & $187(23.4 \%)$ \\
Hindu & $68 \quad(8.5 \%)$ \\
Kristian & $59 \quad(7.6 \%)$ \\
\hline
\end{tabular}

Sumber: Soal Selidik

Jadual 4 pula ialah maklumat mengenai latar belakang responden berkaitan dengan tahap dan jenis pendidikan. Sebahagian besar responden iaitu seramai 564 orang $(70.5 \%)$ mengikuti aliran sekolah kebangsaan di 
peringkat sekolah rendah dan majoriti iaitu seramai 691 orang $(86.4 \%)$ seterusnya menyambung pelajaran di sekolah-sekolah menengah kebangsaan di seluruh negara. Di sekolah jenis kebangsaan pula, seramai 236 orang (29.5\%) dan di peringkat sekolah menengah jenis kebangsaan seramai 109 orang $(13.6 \%)$.

Jadual 4: Pendidikan Responden

\begin{tabular}{|l|ll|}
\hline$n=800$ & \multicolumn{2}{|c|}{ Bilangan dan Peratusan } \\
\hline Jenis Pendidikan Rendah: & & \\
Sekolah Kebangsaan & 564 & $(70.5 \%)$ \\
Sekolah Jenis Kebangsaan & 236 & $(29.5 \%)$ \\
\hline Jenis Pendidikan Menengah: & & \\
Sekolah Kebangsaan & & \\
Sekolah Jenis Kebangsaan & $691 \quad(86.4 \%)$ \\
& $109 \quad(13.6 \%)$ \\
\hline
\end{tabular}

Sumber: Soal Selidik

\section{Respons Pelajar Terhadap Pluraliti Agama di Malaysia}

Respons pelajar terhadap peruntukan Islam dan orang Melayu juga diambil dalam soal selidik ini. Jadual 5 yang merekodkan respons pelajar, menunjukkan bahawa sebahagian besar $(70 \%)$ pelajar mempunyai tanggapan setuju bahawa agama Islam mempunyai kedudukan yang lebih baik berbanding agama lain di Malaysia, amalan interaksi antara agama berlaku secara aman dan harmoni di Malaysia dan Malaysia ialah sebuah negara plural atau berbilang agama. Namun kurang $50 \%$ pelajar bersetuju soal beragama ialah hak kebebasan setiap individu. Hal yang sama juga iaitu $43.7 \%$ pelajar bersetuju setiap individu mesti mengetahui prinsip asasi agama lain sebagai pra syarat dalam masyarakat plural. Manakala hanya 29.2\% sahaja yang bersetuju setiap agama mempunyai kebenaran yang sama. 
Mohd Farid \& Khadijah, "Respons Pelajar IPTA terhadap Pluraliti Agama di Malaysia," Afkär Vol. 19 Issue 1 (2017): 1-40

Jadual 5: Respons Pelajar Secara Keseluruhan

\begin{tabular}{|c|c|c|c|}
\hline Item & $\begin{array}{l}\text { Tidak } \\
\text { Setuju } \\
\end{array}$ & $\begin{array}{l}\text { Kurang } \\
\text { Setuju }\end{array}$ & Setuju \\
\hline $\begin{array}{lr}\text { Islam mempunyai } \\
\text { kedudukan yang } \\
\text { lebih } & \text { baik } \\
\text { berbanding agama } \\
\text { lain di Malaysia }\end{array}$ & $56(7.0)$ & 109 (13.6) & $635(79.4)$ \\
\hline $\begin{array}{l}\text { Amalan interaksi } \\
\text { antara agama } \\
\text { berlaku secara aman } \\
\text { dan harmoni di } \\
\text { Malaysia }\end{array}$ & $30(3.8)$ & $108(13.5)$ & $662(82.7)$ \\
\hline $\begin{array}{l}\text { Malaysia ialah } \\
\text { sebuah negara plural } \\
\text { agama. }\end{array}$ & $145(18.1)$ & $151(18.9)$ & $504(63.0)$ \\
\hline $\begin{array}{lr}\text { Setiap } & \text { individu } \\
\text { mesti mengetahui } \\
\text { prinsip asasi agama } \\
\text { lain sebagai pra } \\
\text { syarat dalam } \\
\text { masyarakat plural } \\
\end{array}$ & 231 (28.9) & $220(27.5)$ & $349(43.7)$ \\
\hline $\begin{array}{l}\text { Setiap agama adalah } \\
\text { benar }\end{array}$ & $325(40.6)$ & $241(30.1)$ & $234(29.2)$ \\
\hline $\begin{array}{l}\text { Soal beragama ialah } \\
\text { hak kebebasan setiap } \\
\text { individu }\end{array}$ & $240(30.0)$ & 175 (21.9) & $385(48.1)$ \\
\hline
\end{tabular}

Respons Pelajar Terhadap Pluraliti Agama di Malaysia Mengikut Agama, Jenis Pendidikan Sekolah Rendah dan Jenis Pendidikan Sekolah Menengah

Respons pelajar terhadap pluralisme agama juga ditinjau berdasarkan faktor-faktor seperti agama, jenis pendidikan sekolah rendah dan jenis pendidikan sekolah menengah. Jadual 6 mendapati bahawa pelajar beragama Islam $(94.8 \%)$ bersetuju dengan Islam mempunyai kedudukan yang lebih baik di Malaysia berbanding pelajar Buddha $(50.2 \%)$, Hindu $(58.8 \%)$ dan Kristian (71.2\%). Namun, 
Mohd Farid \& Khadijah, "Respons Pelajar IPTA terhadap Pluraliti Agama di Malaysia," Afkār Vol. 19 Issue 1 (2017): 1-40

bagi faktor seperti aliran pendidikan rendah dan menengah, didapati terdapat perbezaan yang agak ketara.

Jadual 6: Respons Pelajar Mengikut Demografi

Islam mempunyai kedudukan yang lebih baik berbanding agama lain di Malaysia

\begin{tabular}{|c|c|c|c|}
\hline & $\begin{array}{l}\text { Tidak } \\
\text { Setuju }\end{array}$ & $\begin{array}{l}\text { Kurang } \\
\text { Setuju }\end{array}$ & Setuju \\
\hline $\begin{array}{l}\text { Agama: } \\
\text { Islam } \\
\text { Buddha } \\
\text { Hindu } \\
\text { Kristian } \\
\end{array}$ & $\begin{array}{c}6(0.8) \\
19(15.5) \\
12(27.7) \\
9(17.3)\end{array}$ & $\begin{array}{c}23(4.3) \\
64(34.2) \\
16(23.5) \\
6(11.5)\end{array}$ & $\begin{array}{c}464(94.8) \\
94(50.2) \\
40(58.8) \\
37(71.2)\end{array}$ \\
\hline $\begin{array}{l}\text { Jenis Pendidikan } \\
\text { Rendah: } \\
\text { Sekolah Kebangsaan } \\
\text { Sekolah r Jenis } \\
\text { Kebangsaan }\end{array}$ & $\begin{array}{c}18(3.2) \\
38(16.1)\end{array}$ & $\begin{array}{c}38(6.7) \\
71(30.1)\end{array}$ & $\begin{array}{l}508(90.1) \\
127(53.8)\end{array}$ \\
\hline $\begin{array}{l}\text { Jenis Pendidikan } \\
\text { Menengah: } \\
\text { Sekolah Kebangsaan } \\
\text { Sekolah Jenis } \\
\text { Kebangsaan }\end{array}$ & $\begin{array}{c}44(6.5) \\
11(10.1)\end{array}$ & $\begin{array}{l}78(11.3) \\
31(28.4)\end{array}$ & $\begin{array}{c}568(82.2) \\
67(61.5)\end{array}$ \\
\hline
\end{tabular}

Sumber: Soal Selidik

Secara keseluruhan respons pelajar terhadap persetujuan peruntukan Islam iaitu amalan interaksi antara agama berlaku secara aman dan harmoni di Malaysia adalah tinggi iaitu melebihi $70 \%$ bagi semua faktor demografi dan diterima dengan baik oleh pelajar seperti Jadual 7.

Jadual 7: Respons Pelajar Mengikut Demografi

Amalan interaksi antara agama berlaku secara aman dan harmoni di Malaysia

\begin{tabular}{|l|c|c|c|}
\hline & $\begin{array}{c}\text { Tidak } \\
\text { Setuju }\end{array}$ & $\begin{array}{c}\text { Kurang } \\
\text { Setuju }\end{array}$ & Setuju \\
\hline Agama: & $11(2.2)$ & $53(10.9)$ & $421(86.8)$ \\
Islam & $9(4.8)$ & $28(15.0)$ & $150(80.3)$ \\
Buddha & $5(7.4)$ & $13(19.1)$ & $48(73.5)$ \\
Hindu & \multicolumn{2}{|l}{} \\
\hline
\end{tabular}


Mohd Farid \& Khadijah, "Respons Pelajar IPTA terhadap Pluraliti Agama di Malaysia," Afkār Vol. 19 Issue 1 (2017): 1-40

\begin{tabular}{|l|c|c|c|}
\hline Kristian & $4(7.7)$ & $11(21.1)$ & $37(71.1)$ \\
\hline Jenis Pendidikan & & & \\
Rendah: & & & \\
Sekolah Kebangsaan & $17(3.0)$ & $67(11.9)$ & $480(85.1)$ \\
Sekolah Jenis & $13(5.5)$ & $4(17.4)$ & $182(77.1)$ \\
Kebangsaan & & & \\
\hline Jenis Pendidikan & & & \\
Menengah: & & & \\
Sekolah Kebangsaan & $25(3.6)$ & $91(13.2)$ & $575(83.6)$ \\
Sekolah Jenis & $5(4.6)$ & $17(15.6)$ & $87(79.8)$ \\
Kebangsaan Sumber: Soal Selidik & \\
\hline
\end{tabular}

Respons pelajar terhadap Malaysia ialah sebuah negara plural atau berbilang agama adalah mengikut faktor demografi seperti dinyatakan dalam Jadual 8 . Berdasarkan agama didapati bahawa pelajar Islam (73.4\%) bersetuju berbanding pelajar Buddha (45.9\%), Hindu (50.0\%) dan Kristian (50.0\%) bahawa Malaysia adalah sebuah negara plural agama. Bagi jenis pendidikan pula, didapati sekolah kebangsaan lebih tinggi tahap persetujuan.

Jadual 8: Respons Pelajar Mengikut Demografi

\begin{tabular}{|l|c|c|c|}
\hline \multicolumn{4}{|c|}{ Malaysia ialah sebuah negara plural agama } \\
\hline & $\begin{array}{c}\text { Tidak } \\
\text { Setuju }\end{array}$ & $\begin{array}{c}\text { Kurang } \\
\text { Setuju }\end{array}$ & Setuju \\
\hline Agama: & $53(10.9)$ & $76(15.7)$ & $356(73.4)$ \\
Islam & $47(25.1)$ & $54(28.9)$ & $86(45.9)$ \\
Buddha & $26(38.2)$ & $8(11.8)$ & $34(50.0)$ \\
Hindu & $15(28.8)$ & $11(21.2)$ & $26(50.0)$ \\
Kristian & & & \\
Jenis Pendidikan & & $49(15.8)$ & $393(69.7)$ \\
Rendah: & & & $111(47.0)$ \\
Sekolah Kebangsaan & $82(14.6)$ & $62(26.3)$ & \\
Sekolah Jenis & $63(26.7)$ & & \\
Kebangsaan Pendidikan & & & \\
\hline Jenis Pen (63.9) \\
Menengah:
\end{tabular}


Mohd Farid \& Khadijah, "Respons Pelajar IPTA terhadap Pluraliti Agama di Malaysia," Afkār Vol. 19 Issue 1 (2017): 1-40

\begin{tabular}{|l|c|c|c|}
\hline $\begin{array}{l}\text { Sekolah Jenis } \\
\text { Kebangsaan }\end{array}$ & $22(20.2)$ & $25(22.9)$ & $62(56.9)$ \\
\hline
\end{tabular}

Jadual 9 mendapati persepsi pelajar terhadap keperluan setiap individu mesti mengetahui prinsip asasi agama lain sebagai pra syarat dalam masyarakat plural, berdasarkan agama tidak terdapat perbezaan yang ketara antara pelajar Islam (42.3\%), Buddha (51.9\%), Hindu (38.7\%) dan Kristian (38.4\%).

Jadual 9: Respons Pelajar Mengikut Demografi

\begin{tabular}{|l|c|c|c|}
\hline \multicolumn{4}{|c|}{$\begin{array}{c}\text { Setiap individu mesti mengetahui prinsip asasi agama lain } \\
\text { sebagai pra syarat dalam masyarakat plual }\end{array}$} \\
\hline & $\begin{array}{c}\text { Tidak } \\
\text { Setuju }\end{array}$ & $\begin{array}{c}\text { Kurang } \\
\text { Setuju }\end{array}$ & Setuju \\
\hline Agama: & $170(35.0)$ & $110(22.7)$ & $202(42.3)$ \\
Islam & $25(13.4)$ & $65(34.8)$ & $97(51.9)$ \\
Buddha & $22(32.3)$ & $22(32.4)$ & $24(38.7)$ \\
Hindu & $13(25.0)$ & $19(36.5)$ & $20(38.4)$ \\
Kristian & & & \\
\hline Jenis Pendidikan & & $128(22.7)$ & $243(43.1)$ \\
Rendah: & $193(34.2)$ & $92(39.0)$ & $106(44.9)$ \\
Sekolah Kebangsaan & & & \\
Sekolah Jenis & $38(16.1)$ & & \\
Kebangsaan Pendidikan & & $182(26.3)$ & $300(43.4)$ \\
\hline Jenis Penengah: & & $38(34.9)$ & $49(44.9)$ \\
Menengah: & $209(30.3)$ & \\
Sekolah Kebangsaan & & & \\
Sekolah & & & \\
Kebangsaan Jenis & $22(20.2)$ & &
\end{tabular}

Sumber: Soal Selidik

Secara keseluruhan, majoriti pelajar tidak bersetuju $(40.6 \%)$ bahawa setiap agama adalah benar. Berdasarkan demografi dalam Jadual 10, didapati tahap tidak bersetuju pelajar Islam, Buddha dan Kristian adalah tinggi iaitu melebihi $40 \%$ kecuali bagi pelajar Hindu kurang daripada $30 \%$. 
Mohd Farid \& Khadijah, "Respons Pelajar IPTA terhadap Pluraliti Agama di Malaysia," Afkär Vol. 19 Issue 1 (2017): 1-40

Jadual 10: Respons Pelajar Mengikut Demografi

\begin{tabular}{|l|c|c|c|}
\hline \multicolumn{4}{|c|}{ Setiap agama adalah benar } \\
\hline & $\begin{array}{c}\text { Tidak } \\
\text { Setuju }\end{array}$ & $\begin{array}{c}\text { Kurang } \\
\text { Setuju }\end{array}$ & Setuju \\
\hline Agama: & $205(42.3)$ & $151(31.1)$ & $129(26.5)$ \\
Islam & $80(42.8)$ & $56(29.9)$ & $51(27.3)$ \\
Buddha & $19(28.0)$ & $13(19.1)$ & $36(52.9)$ \\
Hindu & $21(40.4)$ & $17(32.7)$ & $14(26.9)$ \\
Kristian & & & \\
\hline Jenis Pendidikan & & $169(30.0)$ & $74(29.1)$ \\
Rendah: & & & $70(29.7)$ \\
Sekolah Kebangsaan & $231(41.0)$ & & \\
Sekolah Jenis & $94(39.8)$ & $72(30.5)$ & \\
Kebangsaan Pendidikan & & & $206(29.8)$ \\
\hline Jenis & & & \\
Menengah: & & \\
Sekolah Kebangsaan & $270(39.0)$ & $215(31.1)$ & $26(23.9)$ \\
Sekolah & & & \\
Kebangsaan Jenis & $55(50.5)$ & $26.7)$ \\
\hline
\end{tabular}

Sumber: Soal Selidik

Jadual 11 merekodkan respons pelajar terhadap soal beragama ialah hak kebebasan setiap individu. Didapati terdapat perbezaan persetujuan yang sangat ketara antara pelajar Islam (23.3\%), Buddha (87.7\%), Hindu (85.3\%) dan Kristian (84.6\%). Bagi jenis pendidikan kebangsaan dan jenis kebangsaan dilihat terdapat perbezaan yang besar.

Jadual 11: Respons Pelajar Mengikut Demografi

\begin{tabular}{|l|c|c|c|}
\hline \multicolumn{4}{|c|}{ Soal beragama ialah hak kebebasan setiap individu } \\
\hline & $\begin{array}{c}\text { Tidak } \\
\text { Setuju }\end{array}$ & $\begin{array}{c}\text { Kurang } \\
\text { Setuju }\end{array}$ & Setuju \\
\hline Agama: & $227(46.8)$ & $145(29.9)$ & $113(23.3)$ \\
Islam & $6(3.2)$ & $17(9.1)$ & $164(87.7)$ \\
Buddha & $4(5.9)$ & $6(8.8)$ & $58(85.3)$ \\
Hindu & $3(5.8)$ & $5(9.6)$ & $44(84.6)$ \\
Kristian & & & \\
\hline Jenis Pendidikan & & & \\
Rendah: & & & \\
\hline
\end{tabular}


Mohd Farid \& Khadijah, "Respons Pelajar IPTA terhadap Pluraliti Agama di Malaysia," Afkār Vol. 19 Issue 1 (2017): 1-40

\begin{tabular}{|l|c|c|c|}
\hline $\begin{array}{l}\text { Sekolah Kebangsaan } \\
\text { Sekolah Jenis }\end{array}$ & $10(40.8)$ & $147(26.1)$ & $187(33.1)$ \\
Kebangsaan & & $28(11.9)$ & $198(83.9)$ \\
\hline $\begin{array}{l}\text { Jenis Pendidikan } \\
\text { Menengah: } \\
\text { Sekolah Kebangsaan }\end{array}$ & $230(33.3)$ & $158(22.9)$ & $303(43.9)$ \\
$\begin{array}{l}\text { Sekolah Jenis } \\
\text { Kebangsaan }\end{array}$ & $10(9.2)$ & $17(15.6)$ & $82(75.3)$ \\
\hline \multicolumn{4}{|c|}{ Sumber: Soal Selidik } \\
\hline
\end{tabular}

\section{Analisis}

Menghadapi cabaran yang ditimbulkan oleh pluraliti agama bukannya mudah. Pelbagai usaha dijalankan oleh individu, badan berkanun dan pihak berautoriti yang melaksanakan program-program penerangan kepada masyarakat. Antara program-program yang telah diperkenalkan oleh negara untuk menangani isu pluraliti agama ini termasuklah forum, seminar, hinggalah kepada penerbitan risalah dan buku-buku di samping banyak lagi program yang memfokuskan kepada kelompok masyarakat awam.

Di peringkat pengajian tinggi pula, fokus diberikan kepada pengajaran dan pembelajaran tentang disiplin perbandingan agama dengan harapan akan timbul kefahaman dalam kalangan mahasiswa terhadap kehendak dan tuntutan dalam agama-agama selain Islam. Pengenalan kursus-kursus ini pada asasnya sudah bersesuaian dan bertindan dengan cabaran-cabaran terkini yang dihadapi oleh negara. Contohnya, bila isu berkaitan kemelut penggunaan kalimah Allah oleh golongan bukan Islam timbul dan dipolemikkan oleh sebahagian kelompok, penjelasan tentangnya telahpun sebenarnya dikupas dalam kursus-kursus perbandingan agama.

Respons pelajar secara keseluruhan terhadap aspek pluraliti di Malaysia adalah baik seperti Islam mempunyai kedudukan yang lebih baik berbanding dengan agamaagama lain, amalan interaksi antara agama berlaku secara aman dan harmoni di Malaysia dan Malaysia ialah sebuah 
negara plural. Namun pelajar kurang bersetuju bahawa soal beragama ialah hak kebebasan setiap individu, setiap individu mesti mengetahui prinsip asasi agama lain sebagai pra syarat dalam masyarakat plural dan mereka juga kurang bersetuju bahawa setiap agama adalah benar. Hasil kajian mengikut demografi menunjukkan bahawa terdapat perbezaan yang ketara mengikut agama, jenis pendidikan sekolah rendah dan jenis pendidikan sekolah menengah. Oleh itu, jelas daripada analisis data melalui soal selidik menunjukkan bahawa respons pelajar secara keseluruhan terhadap pluralisme agama di Malaysia tidak dipersetujui dengan baik oleh pelajar. Namun pelajar bersetuju bahawa Malaysia ialah sebuah negara plural agama dan proses interaksi antara agama berjalan dengan baik.

Selain itu, hasil soal selidik menunjukkan faktor agama dan jenis pendidikan sekolah rendah dan menengah sangat mempengaruhi respons pelajar terhadap pluraliti agama. Rumusan dapatan soal selidik ini selari dengan kajian Amir Dawi Hasan ${ }^{48}$, Mansor Mohd Noor ${ }^{49}$ dan Fazilah Idris ${ }^{50}$. Oleh itu, dua faktor ini sangat relevan dalam mencorakkan interaksi antara agama dan kaum di Malaysia, malah menjadi satu agenda yang patut diberi perhatian.

\section{Kesimpulan}

Penulis berpandangan bahawa pengenalan kursus perbandingan agama pada peringkat sekolah pada masa ini dilihat penting sebagai salah satu usaha untuk menangani

${ }^{48}$ Amir Dawi Hassan, "Hubungan Etnik di IPT: Satu Kajian Etnografi dan Model Budaya di Kalangan Pelajar Berlainan Etnik," (tesis PhD, Universiti Kebangsaan Malaysia, 2004).

${ }^{49}$ Mansor Mohd Noor, Integrasi Etnik di IPTA (Pulau Pinang: Institut Penyelidikan Pendidikan Tinggi Negara, 2005).

${ }^{50}$ Fazilah Idris, "The Influence of Individual Attributes on Inter-Ethnic Tolerance Among Early Youth in Selangor," (tesis PhD, Universiti Putra Malaysia. 2008). 
masalah salah faham antara agama yang sering menjadi isu dalam proses pembangunan negara. Huraian di atas yang berdasarkan kajian soal selidik menunjukkan bahawa kursus perbandingan agama di sekolah adalah sesuatu yang sangat perlu. Fokusnya kepada golongan pelajar di sekolah kebangsaan atau sekolah jenis kebangsaan adalah sesuai, dan usaha-usaha semua golongan dalam perkara ini haruslah disokong dan dibantu.

Pengenalan kursus seumpama ini adalah yang terbaik kepada golongan ini kerana di samping didedahkan kepada teori agama-agama dunia, mereka juga akan mendapat peluang untuk melihat sendiri landskap tempattempat ibadat agama-agama selain Islam yang bukan sahaja dapat menambah ilmu tentang isu yang difokuskan, tetapi lebih penting lagi dapat menghilangkan prejudis terhadap penganut agama lain. Namun, cabaran terhadap usaha-usaha ini sentiasa wujud. Maka semua usaha ini perlu dilakukan dalam keadaan kita sedar bahawa memahami perbezaan agama bukanlah sesuatu yang hanya boleh diteorikan kepada masyarakat, terutamanya golongan remaja. Sebaliknya usaha ini sesuatu yang seharusnya dikongsi dan dilalui bersama.

Peringkat pengajian di sekolah dilihat penting kerana pada waktu itu para pelajar mempelajari pelajaranpelajaran yang paling berguna dalam hidup mereka dan yang akan menjadi pegangan hidup mereka kelak. Pada waktu itu juga mereka secara umumnya belum dipengaruhi dengan kesan-kesan kehidupan baik yang positif mahupun yang negatif. Umum mengetahui bahawa pengaruh kepada kelompok pelajar ini yang paling utama pada tahap itu ialah ibu bapa, ahli keluarga, dan guruguru. Kelompok inilah yang perlu diberikan perhatian yang lebih serius kerana dari sinilah semua proses bermula. 


\section{Rujukan}

A. Aziz dan S. A. Baharudin, "The Religious, the Plural, the Secular and the Modern: A Brief Critical Survey on Islam in Malaysia", Inter-Asia Cultural Studies 5(3) (2004): 341-357.

Ahmad Sabri bin Osman. "Konsep Tauhid Menurut Ismail Raji al-Faruqi: Analisis Terhadap Isu-Isu dalam Pluralisme Agama." Tesis PhD, Universiti Sains Malaysia, 2015.

Amir Dawi Hassan. "Hubungan Etnik di IPT: Satu Kajian Etnografi dan Model Budaya di Kalangan Pelajar Berlainan Etnik." Tesis PhD, Universiti Kebangsaan Malaysia. 2004.

Anis Malik Thoha. Tren Pluralisme Agama: Tinjauan Kritis. Jakarta: Gema Insani, 2005.

Awang Hasmadi Awang Mois. "Hubungan Kaum dan Pencapaiannya." Dalam Agenda Pembinaan Negara Bangsa Malaysia Dalam Era Kebangkitan Asia, ed. Mohd Yaakob Hj Johari et.al. Kota Kinabalu: Institut Kajian Pembangunan Sabah, 1997.

Azman Amin Hassan. "Solving Conflicts in a Multicultural Society: The Case of Kampung Medan." Dalam Reading on Ethnic Relations in a Multicultural Society, ed. Muhammad Kamarul Kabilan dan Zaharah Hassan. Serdang: Penerbit UPM, 2005.

Budhy Munawar Rachman. Islam Pluralis: Wacana Kesetaraan Kaum Beriman. Jakarta: Penerbit Paramadina, 2002.

Bukhārī, Abū 'Abd Allāh Muhammad bin Ismā'îl al-. Șaḥ̄ḥ al-Bukhārī, Kitāb al-Diyāt, Bāb al-Qasāmah, juz.

1. Beirut: Dār Ihyā̄’ al-Kutub al-'Arabiyyah, t.t.

Chandra Muzaffar. "Islam and the Future of Inter-Ethnic Relations in Malaysia." Dalam Occasional Paper Series 1. Kuala Lumpur: International Institute of Advanced Islamic Studies (IAIS) Malaysia, t.t. 
Esposito, John L. dan Voll, J. O. Islam and Democracy. New York: Oxford University Press, 1996.

Fazilah Idris. "The Influence of Individual Attributes on Inter-Ethnic Tolerance among Early Youth in Selangor." Tesis PhD, Universiti Putra Malaysia, 2008.

Fenti Hikmawati, "Psychoeducation of Character Personal's Local Wisdom of Sundanese People's Behaviour in Interternalizing Religious Commitment," Tarbiya: Journal of Education in Muslim Society 3(1) 2016: 64-76.

Goh, Daniel P.S. et.al. ed. Race and Multiculturalism in Malaysia and Singapore. London: Routledge, 2009.

Haslina Ibrahim. "Diversity of Religions: An Assessment of the Christian and Muslim Encounters with the Philosophy of Religious Pluralism." Tesis $\mathrm{PhD}$, Universiti Islam Antarabangsa Malaysia, 2005.

Jabatan Perangkaan Malaysia. Taburan Penduduk dan Ciri-Ciri Asas Demografi. Kuala Lumpur: Jabatan Perangkaan Malaysia, 2010.

Kamar Oniah Kamaruzaman. Religion and Pluralistic CoExixtence: The Muhibah Perspective (A Collection of Seminar Papers). Kuala Lumpur: IIUM Press, 2010.

Krejcie, R. V. \& Morgan, D. W. "Determining Sample Size for Research Activities," Educational and Psychology Measurement 30:3, 1970.

Mansor Mohd Noor. Integrasi Etnik di IPTA. Pulau Pinang: Institut Penyelidikan Pendidikan Tinggi Negara, 2005.

Mawdudi, Abul A'la. Towards Understanding Islam. Markfield: The Islamic Foundation, 2000.

Mohd Aizam Mas'od, "Hujah Menolak Penggunaan Kalimah 'Allah' oleh Kristian", Jurnal Penyelidikan Islam 21 (2008): 1-8.

Mohd Farid Mohd Sharif, "Commanding and Forbidding the Imām: A Study of the Concept of al-Amr bi al- 
Ma 'rūf and Nahy 'an al-Munkar in Islamic Imamship," Jurnal Syariah 16(1) 2008: 1-16.

Mohd Farid Mohd Sharif. Maaf...Tuhan Kita Tidak Sama: Mengulas Isu Interaksi Agama di Malaysia. Jitra: Bitara Media, 2012.

Mohd Majid Konting. Kaedah Penyelidikan Pendidikan. Kuala Lumpur: Dewan Bahasa dan Pustaka, 1990.

Muhammadiris Duereh. "Analisis Liberalisme Agama di Malaysia Menurut Perspektif Akidah Islam." Tesis $\mathrm{PhD}$, Universiti Sains Malaysia, 2013.

Muslim b. al-Hajjaj al-Qushayrī al-Naysabūrī. Sahịh Muslim, Kitāb al-Qasāmah wa al-Muḥaribīn wa alQasas wa al-Diyāt, Bāb al-Qasāmah. Qāhirah: Dār Ibn al-Haithām, 2003.

Noor Shakirah Mat Akhir. Al-Ghazali and His Theory of the Soul: A Comparative Study. USM: Penerbit Universiti Sains Malaysia, 2008.

Nurazuki Yusuff. "Pengalaman Konflik Hubungan Etnik di Malaysia: Satu Sorotan." Dalam Islam dan Hubungan Etnik: Perbincangan Isu-Isu Semasa, ed. Alis Putih. Jitra: Pure Honey Enterprise, 2008: 70-79.

Rahimin Affandi Abd. Rahim, "Pendekatan Pluralisme dalam Pengajian Islam: Satu Pengenalan," Jurnal Peradaban 1 (2008): 1-13.

Rahimin Affandi Abd. Rahim et.al., "Dialog Antara Agama: Realiti dan Prospek di Malaysia," Kajian Malaysia 29(2) 2011: 87-106.

Ramadan, Tariq. The Messenger: The Meanings of the Life of Muhammad. London: Penguin Books Ltd., 2007. Ramadan, Tariq. Western Muslims and the Future of Islam. New York: Oxford University Press, 2004.

Roff, William R. The Origins of Malay Nationalism. New Haven: Yale University Press, 1967.

Ros Aiza Mohd Mokhtar dan Che Zarrina Sa'ari, "Konsep Sinkretisme menurut Perspektif Islam," Afkar 17 (2015): 51-78. 
Sidek Mohd Noah. Reka Bentuk Penyelidikan: Falsafah, Teori dan Praktis. Serdang: Penerbit UPM, 2002.

Swidler, Leonard. "Dialogue in Malaysia and the Global Scenario." Dalam Civilisational Dialogue Centre of Monograph Series, No. 1. Kuala Lumpur: Universiti Malaya, 2003.

Tuckman, B.W. Conducting Educational Research. Fort Worth: Harcourt Brace College Publishers, 1999.

Warnk, Holger. "Race and Multiculturalism in Malaysia and Singapore". Dalam The Newsletter, No. 55. IIAS, 2010.

Zaid Ahmad. "Cabaran Hubungan Etnik di Malaysia dan Global". Dalam Hubungan Etnik di Malaysia. Shah Alam: Oxford Fajar, 2006.

Zainuddin, Ruslan et.al. Kenegaraan Malaysia. Shah Alam: Penerbit Fajar Bakti, 2005. 